\title{
Impact of industrial effluents and simulated acid rain on growth, productivity and metal contamination in mungbean (Vigna radiate $\mathrm{L}$.)
}

\author{
Saba Nazir ${ }^{1}$, Qamar uz Zaman ${ }^{1 *}$, Saba Sharif ${ }^{1}$, Faiza Hassan ${ }^{2}$ and Umair \\ Riaz $^{3}$ \\ 1. Department of Environmental Sciences, The University of Lahore-Lahore-Pakistan \\ 2. Department of Chemistry, The University of Lahore-Lahore-Pakistan \\ 3. Soil and Water Testing Laboratory for Research, Bahawalpur-63100-Pakistan \\ *Corresponding author's email: qamar.zaman1@envs.uol.edu.pk \\ Citation \\ Saba Nazir, Qamar uz Zaman, Saba Sharif, Faiza Hassan and Umair Riaz. Impact of industrial effluents and \\ simulated acid rain on growth, productivity and metal contamination in mungbean (Vigna radiate L.). Pure and \\ Applied Biology. Vol. 8, Issue 2, pp1890-1901. http://dx.doi.org/10.19045/bspab.2019.80132
}

\begin{tabular}{llll}
\hline Received: 22/04/2019 & Revised: 24/06/2019 & Accepted: 13/07/2019 & Online First: 17/07/2019 \\
\hline
\end{tabular}

\section{Abstract}

Environmental pollution poses a great health hazard to human beings, animals and plants. Industrial effluents and acid rain are the major pollutants that have a strong influence on the growth of crop plants. A pot trial was conducted to investigate the influence of industrial effluents and simulated acid rain (SAR) on the growth, productivity, biochemical and quality attributes of mungbean crop. The experiment was comprised of various treatments i.e. $\mathrm{T}_{0}=$ Control; $\mathrm{T}_{1}=$ industrial effluents $(25 \%)+$ distilled water (DW) $(75 \%) ; \mathrm{T}_{2}=$ industrial effluents $(50 \%)+\mathrm{DW}$ (50\%); $\mathrm{T}_{3}=$ industrial effluents $(75 \%)+\mathrm{DW}(25 \%) ; \mathrm{T}_{4}=$ pure industrial effluents $(100 \%)$ and $\mathrm{T}_{5}$ $=$ acid rain $(\mathrm{HCl}$ at $\mathrm{pH} 3.5)$. Results revealed that maximum increase in chlorophyll contents $(12.88 \%)$, pods per plant $(27.90 \%)$, nodules per plant $(34.78 \%)$, number of grains per pods (33.33\%), 1000-seeds weight (8.53\%) and seed yield (47.65\%) was observed in $\mathrm{T}_{2}$ as compared to control. Significant increase in the grain metals contents was observed in the $\mathrm{T}_{4}$. However, application of SAR significantly decreases chlorophyll contents (14.11\%), pods per plant $(30.23 \%)$, nodules per plant $(47.82 \%)$, number of grains per pods $(33.33 \%), 1000$-seeds weight (7.01\%) and seed yield (51.40\%) as compared to control. In crux, simulated acid rain and pure form of industrial effluents have toxic effect on the growth, yield and quality of mungbean. The adequate dilution of effluents treatment is therefore needed before the disposal and reuse of wastewaters for irrigation purposes.

Keywords: Acid rain; Growth; Industrial effluents; Mungbean

\section{Introduction}

Since the establishment of civilization human beings used a different type of natural energy for their beneficial purposes. The natural energy of any type used today has a dual effect, made our lives easier and on the other side their obligatory causes have harmful effect on our atmosphere [1]. Large volume 
of pollutants released by using natural resources and these pollutants are not stayed in a definite area and can transfer universally [2]. These pollutants affect the large population of urban and rural areas and productive agricultural land [3].

Environment is mainly polluted by urbanization, installation of factories, vehicular smoke, fossil fuels burning that have amplified the poisonous gases, i.e. $\mathrm{SO}_{\mathrm{x}}$, $\mathrm{CO}$ and $\mathrm{NO}_{\mathrm{x}}$ concentration and other contaminants such as dust, smoke, and fumes [4]. These poisonous gases when moving into air get mixed with humid air and fall on the surface of the earth in various forms like fog, rain, hail, and snow known as acid rain [5]. Some gases like $\mathrm{SO}_{2}$ and $\mathrm{NO}_{2}$ after changing their chemical composition in the air are considered the primary source of acid rain [6]. Acid rain significantly damages the humans, animals, plants and other objects (stones etc.) [7].

Water is our basic need that is gradually threatened and must be sustained; recycling of water and wastewater at universally and locally for irrigation is becoming a progressively successful practice mostly in those areas where good quality water supplies are limited [8, 9]. Vegetative growth, yield and quality of crop basically depend on the type of water we used for irrigation. Irrigation with wastewater having heavy metals higher than the crop can tolerate, will severely affect the crop yield. Specific measures should be adopted before using of this contaminated water [10]. Previous studies indicated that industrial effluents in diluted form could be used for irrigation to improve crops productivity. On the basis of crop types, the dilution factor for industrial effluents is different. In many cases, it can also be seen by different researchers that the application of diluted effluent may change the physiochemical soil properties (essential to acidic) and it may be toxic for crops [11].
In the legumes, one of the essential crops that gained interest due to its medical importance and nutritional status is the mungbean [12]. Mainly it is cultivated in the different regions of the Asia, including India, China, Thailand, Pakistan, Philippines, and Indonesia. In Pakistan, it is main summer pulse crop also called as the green gram [13]. Roots of legumes have nodules that contain particular types of microbes called the rhizobacteria that can fix atmospheric nitrogen ultimately enhancing the soil fertility [14].

The higher levels of industrial effluents and SAR are very toxic for mungbean and its tolerance capability differs during the life cycle of mungbean plant. However, very less information is known about the effect of industrial effluents and acid rain on growth, yield and quality attributes of the mungbean. Consequently, the present investigation was directed to observe the reaction of industrial effluent at different concentrations and SAR on the growth, productivity, biochemical and quality of mungbean.

\section{Materials and methods}

\section{Study site, sample collection, experimental design, and treatments}

A pot trial was conducted at the Department of Environmental Sciences, The University of Lahore, Lahore, Pakistan during 2018. Industrial effluent (textile, marble, and brewages) was taken from Rohi Drain (Defence Road, Lahore, Pakistan) in presterilized plastic containers, brought to the laboratory and subjected to different tests for analysis using the protocols of Clesceri et al. [15] as depicted in the (Table 1). Simulated acid rain was prepared by mixing the $\mathrm{HCl}$ in water $(\mathrm{HCl}$ at $\mathrm{pH} 3.5)$. The experiment was comprised of $\mathrm{T}_{0}=$ Control; $\mathrm{T}_{1}=$ industrial effluents $(25 \%)+$ distill water $(75 \%) ; \mathrm{T}_{2}=$ industrial effluents $(50 \%)+\mathrm{DW}(50 \%) ; \mathrm{T}_{3}=$ industrial effluents $(75 \%)+\mathrm{DW}(25 \%) ; \mathrm{T}_{4}=$ pure industrial effluents $(100 \%)$ and $\mathrm{T}_{5}=$ acid rain $(\mathrm{HCl}$ at $\mathrm{pH} 3.5)$. Completely randomized design (CRD) was used in this experiment, 
and each treatment was replicated three times. The total pots were 18 (6 industrial effluents and simulated acid rain treatments $\times 3$ replicates).

\section{Crop husbandry}

The planned trial was conducted in 18 pots $(45 \mathrm{~cm} \times 30 \mathrm{~cm}$ diameter) allocating three pots for each treatment. Each pot was filled with a $5 \mathrm{~kg}$ mixture of soil and sand (70\% soil and $30 \%$ sand). The crop was sown on $12^{\text {th }}$ July 2018 using tens seeds per pot. After the seedling establishment, five plants per pot were maintained by thinning. The fertilizer was applied @ 270:600:520 mg pot ${ }^{-1}$ NPK, using sources of urea, triple super phosphate, and sulphate of potash, respectively. Irrigations were applied when required. Experimental treatments were applied 40 days after sowing. To avoid weed-crop competition hand weeding was done. All other treatments were kept under normal and uniform agronomic condition. The crop was harvested on $12^{\text {th }}$ October 2018.

\section{Data collection}

All the growth and yield attributes (plant height, leaves, stem and plant weight (fresh and dry), no. of pods/ plant, pod length, no. of nodules/ plant, number of grains/ pod, 1000-seed weight and seed yield) were recorded by following the Rab et al. [16]. The crop was harvested at maturity, and manual threshing was performed to separate the seeds from the pods. For chlorophyll contents, $0.5 \mathrm{~cm}$ sections of fresh leaves were taken in $80 \%$ acetone at $-10^{\circ} \mathrm{C}$, these sections were extracted after keeping them overnight. After that, the extract of leaves was centrifuged at the rate $14000 \mathrm{rpm}$ for $5 \mathrm{~min}$, and supernatant absorbance was read at 645 and $663 \mathrm{~nm}$ using a spectrophotometer (T60 U Spectrophotometer PG Instruments, Limited, USA), by following the protocols of Nagata and Yamashita, [17]. By following protocols of Jones and Case, [18] grain Cr, $\mathrm{Cu}, \mathrm{Ni}$, and $\mathrm{Zn}$ contents were measured.

\section{Data analysis}

Statistical analysis of data was done by using Statistix 8.1 (Analytical computer software). For the comparison of treatments means, oneway ANOVA and the least significance difference (LSD) test at 5\% probability was applied.

\section{Results}

\section{Growth attributes}

Data regarding different growth attributes showed significant influence $(p \leq 0.05)$ for all the experimental treatments. Maximum fresh weight of leaves $(25.85 \mathrm{~g})$, fresh weight of stem (39.64 g), fresh weight of plants (65.47 g), dry weight of leaves (3.95 g), dry weight of stem $(5.87 \mathrm{~g})$ and dry weight of plant $(9.85$ g) was noticed in $\mathrm{T}_{2}$ where industrial effluents $(50 \%)+$ distill water $(50 \%)$ was applied followed by in $\mathrm{T}_{1}$ and $\mathrm{T}_{3}$ (Table $2 \&$ $3)$. While minimum fresh weight of leaves $(40.04 \mathrm{~g})$, fresh weight of stem $(59.53 \mathrm{~g})$, fresh weight of plants $(99.60 \mathrm{~g})$, dry weight of leaves $(2.37 \mathrm{~g})$, dry weight of stem (4.22 g) and dry weight of plant (6.60 g) was observed in $\mathrm{T}_{5}$ where exogenous application of simulated acid rain $(\mathrm{HCl}$ at $\mathrm{pH} 3.5)$ was applied as associated with control (Table $2 \&$ 3).

\section{Yield attributes}

Results regarding yield attributes showed a significant effect $(p \leq 0.05)$ for all the experimental treatments of industrial effluents and simulated acid rain (Table 4). Maximum plant height $(70.0 \mathrm{~cm})$, pods per plant (27.50), nodules per plant (7.75), pod length $(13.7 \mathrm{~cm})$, no. of grains/ plant $(11.00)$ and 1000-seed weight $(57.09 \mathrm{~g})$ was observed in $\mathrm{T}_{2}$ where industrial effluents $(50 \%)+$ distill water $(50 \%)$ was applied followed by in $T_{1}$ and $T_{3}$. While minimum plant height $(57.5 \mathrm{~cm})$, pods/plant (15.00), nodules/plant (3.00), pod length $(5.4 \mathrm{~cm})$, no. of grains/plant (5.50) and 1000-seed weight $(48.91 \mathrm{~g})$ was observed in $\mathrm{T}_{5}$ where exogenous application of $\mathrm{SAR}(\mathrm{HCl}$ at $\mathrm{pH}$ 3.5) was applied in comparison with control 
(Table 4). A similar trend was observed in the case of chlorophyll contents and seed yield per plant as depicted in (Figure $1 \& 2$ ).

Heavy metal contents in mungbean grains Data regarding heavy metal $(\mathrm{Zn}, \mathrm{Cr}, \mathrm{Cu}$, and $\mathrm{Ni}$ ) contents in a grain of mungbean showed significant effect $(p \leq 0.05)$ for all the experimental treatments of industrial effluents and simulated acid rain. Maximum grain $\mathrm{Cr}$ (8.70 ppm), Ni (8.12 ppm), Cu (7.22 ppm) and $\mathrm{Zn}(7.98 \mathrm{ppm})$ contents were observed in $\mathrm{T}_{4}$, where pure industrial effluents $(100 \%)$ was applied followed by $\mathrm{T}_{3}$ and $\mathrm{T}_{4}$ while minimum grain $\mathrm{Cr}(0.89 \mathrm{ppm})$, $\mathrm{Ni}$ (1.08 ppm), Cu (1.03 ppm) and Zn (2.07 ppm) contents were observed in $T_{5}$ where exogenous application of simulated acid rain $(\mathrm{HCl}$ at $\mathrm{pH} 3.5)$ was applied in comparison with control (Figure 3).

\section{Discussion}

Water quality degradation is a major concern as industrial development, huge volume of wastes which is great hazard for public health [19]. Wastewater of different industries has cations and anions which can be valuable for the growth of the plant, but at the tolerance level and after tolerate level, it could be toxic for the growth of the plant. Whole food chain affected by using wastewater of industries that contribute to water pollution, up to an adequate level certain physical, chemical and biological attributes of water are good for health but become toxic at extreme level [20]. From the current study, it is obvious that all the industrial effluents at various levels and simulated acid rain treatments significantly affected biomass of leaves (fresh and dry), stem and plant (Table $2 \& 3$ ). Compared to control, at different levels of effluent had both stimulatory and inhibitory effects on seedling and plant growth. It had a stimulatory effect when $50 \%$ of distilled water was used. The plant absorbs various essential micronutrients for their growth and development [21]. However, above an optimum concentration, they may cause various disturbances to the plant system [22].

Table 1. Characterization of industrial effluent used for the irrigation

\begin{tabular}{|l|c|}
\hline \multicolumn{1}{|c|}{ Parameters } & Values (Means \pm SE) \\
\hline $\mathrm{pH}$ & $7.10 \pm 0.12$ \\
\hline Electrical Conductivity $(\mu \mathrm{S} / \mathrm{cm})$ & $9.12 \pm 0.16$ \\
\hline Turbidity $(\mathrm{NTU})$ & $24.32 \pm 2.13$ \\
\hline TDS $(\mathrm{ppm})$ & $7.34 \pm 1.92$ \\
\hline Total alkalinity $(\mathrm{ppm})$ & $302 \pm 4.45$ \\
\hline Phosphate contents $(\mathrm{ppm})$ & $0.12 \pm 0.02$ \\
\hline Sulphate contents $(\mathrm{ppm})$ & $14.12 \pm 2.23$ \\
\hline Nitrate contents $(\mathrm{ppm})$ & $32.23 \pm 5.23$ \\
\hline Ammonia $(\mathrm{ppm})$ & $23.34 \pm 3.21$ \\
\hline
\end{tabular}

TDS = Total dissolved solids; NTU = Nephelometric Turbidity Unit 
Table 2. Fresh weight of leaves, stem and plant as affected by the industrial effluents and simulated acid rain in mungbean

\begin{tabular}{|l|c|c|c|}
\hline \multicolumn{1}{|c|}{ Experimental Treatments } & $\begin{array}{c}\text { Fresh Weight of Leaves } \\
(\mathbf{g})\end{array}$ & $\begin{array}{c}\text { Fresh Weight of Stem } \\
(\mathbf{g})\end{array}$ & $\begin{array}{c}\text { Fresh Weight of Plant } \\
(\mathbf{g})\end{array}$ \\
\hline $\mathrm{T}_{\mathrm{o}}=$ Control & $33.38 \pm 0.80 \mathrm{~d}$ & $51.76 \pm 0.36 \mathrm{c}$ & $85.15 \pm 0.93 \mathrm{~d}$ \\
\hline $\mathrm{T}_{1}=$ Industrial effluents $(25 \%)+$ Distill water $(75 \%)$ & $37.59 \pm 0.84 \mathrm{~b}$ & $57.81 \pm 0.61 \mathrm{ab}$ & $95.37 \pm 1.24 \mathrm{~b}$ \\
\hline $\mathrm{T}_{2}=$ Industrial effluents $(50 \%)$ + Distill water $(50 \%)$ & $40.04 \pm 0.61 \mathrm{a}$ & $59.53 \pm 0.61 \mathrm{a}$ & $99.60 \pm 1.19 \mathrm{a}$ \\
\hline $\mathrm{T}_{3}=$ Industrial effluents $(75 \%)+$ Distill water $(25 \%)$ & $35.48 \pm 0.70 \mathrm{c}$ & $54.71 \pm 0.91 \mathrm{bc}$ & $90.20 \pm 0.92 \mathrm{c}$ \\
\hline $\mathrm{T}_{4}=$ Pure industrial effluents $(100 \%)$ & $32.04 \pm 0.70 \mathrm{~d}$ & $48.15 \pm 0.43 \mathrm{~d}$ & $80.20 \pm 0.82 \mathrm{e}$ \\
\hline $\mathrm{T}_{5}=$ Acid rain $(\mathrm{HCl}$ at $\mathrm{pH} 3.5)$ & $25.85 \pm 0.51 \mathrm{e}$ & $39.64 \pm 0.81 \mathrm{e}$ & $65.47 \pm 0.53 \mathrm{f}$ \\
\hline LSD $(\boldsymbol{p} \leq \mathbf{0 . 0 5})$ & $\mathbf{2 . 0 8}$ & $\mathbf{3 . 3 0}$ & $\mathbf{4 . 0 2}$ \\
\hline F-value & $\mathbf{4 9 . 5 0 * *}$ & $\mathbf{4 2 . 9 0 * *}$ & $\mathbf{8 1 . 2 0 * *}$ \\
\hline
\end{tabular}

Any two means within a column followed by same letters are not significant at $p \leq 0.05 . \mathrm{n}=3$; ** = Highly Significant at $p \leq 0.01$

Table 3. Dry weight of leaves, stem and plant as affected by the industrial effluents and simulated acid rain in mungbean

\begin{tabular}{|l|c|c|c|}
\multicolumn{1}{|c|}{ Experimental Treatments } & $\begin{array}{c}\text { Dry Weight of Leaves } \\
(\mathbf{g})\end{array}$ & $\begin{array}{c}\text { Dry Weight of Stem } \\
\text { (g) }\end{array}$ & $\begin{array}{c}\text { Dry Weight of Plant } \\
\text { (g) }\end{array}$ \\
\hline $\mathrm{T}_{\mathrm{o}}=$ Control & $3.28 \pm 0.06 \mathrm{c}$ & $5.36 \pm 0.06 \mathrm{~d}$ & $8.65 \pm 0.08 \mathrm{~d}$ \\
\hline $\mathrm{T}_{1}=$ Industrial effluents $(25 \%)$ + Distill water $(75 \%)$ & $3.61 \pm 0.05 \mathrm{~b}$ & $5.70 \pm 0.05 \mathrm{~b}$ & $9.32 \pm 0.10 \mathrm{~b}$ \\
\hline $\mathrm{T}_{2}=$ Industrial effluents $(50 \%)+$ Distill water $(50 \%)$ & $3.95 \pm 0.05 \mathrm{a}$ & $5.87 \pm 0.05 \mathrm{a}$ & $9.85 \pm 0.10 \mathrm{a}$ \\
\hline $\mathrm{T}_{3}=$ Industrial effluents $(75 \%)+$ Distill water $(25 \%)$ & $3.50 \pm 0.07 \mathrm{c}$ & $5.53 \pm 0.06 \mathrm{c}$ & $9.00 \pm 0.12 \mathrm{c}$ \\
\hline $\mathrm{T}_{4}=$ Pure industrial effluents $(100 \%)$ & $2.89 \pm 0.05 \mathrm{~d}$ & $4.75 \pm 0.05 \mathrm{e}$ & $7.62 \pm 0.06 \mathrm{e}$ \\
\hline $\mathrm{T}_{5}=$ Acid rain $(\mathrm{HCl}$ at $\mathrm{pH} 3.5)$ & $2.37 \pm 0.07 \mathrm{e}$ & $4.22 \pm 0.05 \mathrm{f}$ & $6.60 \pm 0.11 \mathrm{f}$ \\
\hline LSD $(\boldsymbol{p} \leq \mathbf{0 . 0 5})$ & $\mathbf{0 . 1 7}$ & $\mathbf{0 . 1 6}$ & $\mathbf{0 . 2 9}$ \\
\hline F-value & $\mathbf{8 8 . 0 0 * *}$ & $\mathbf{1 3 0 . 0 0 * *}$ & $\mathbf{1 4 8 . 0 0 * *}$ \\
\hline
\end{tabular}

Any two means within a column followed by same letters are not significant at $p \leq 0.05 . \mathrm{n}=3$; ** $=$ Highly Significant at $p \leq 0.01$ 
Khan et al.

Table 4. Growth and yield as affected by the industrial effluents and simulated acid rain in mungbean

\begin{tabular}{|c|c|c|c|c|c|c|}
\hline Experimental Treatments & $\begin{array}{c}\text { PH } \\
(\mathbf{c m})\end{array}$ & PPP & NPP & $\begin{array}{l}\text { PL } \\
(\mathbf{c m})\end{array}$ & NGPP & $\begin{array}{c}\text { 1000-SW } \\
\text { (g) }\end{array}$ \\
\hline $\mathrm{T}_{\mathrm{o}}=$ Control & $63.7 \pm 1.70 \mathrm{~b}$ & $21.50 \pm 0.65 \mathrm{c}$ & $5.75 \pm 0.63$ a & $9.2 \pm 0.82 \mathrm{c}$ & $8.25 \pm 0.63 \mathrm{c}$ & $52.60 \pm 0.82 \mathrm{~cd}$ \\
\hline $\mathrm{T}_{1}=$ Industrial effluents $(25 \%)+$ Distill water $(75 \%)$ & $67.9 \pm 1.88 \mathrm{ab}$ & $25.25 \pm 1.11 \mathrm{ab}$ & $6.25 \pm 0.25 \mathrm{ab}$ & $11.8 \pm 0.63 \mathrm{ab}$ & $10.00 \pm 0.41 \mathrm{ab}$ & $55.64 \pm 0.60 \mathrm{ab}$ \\
\hline $\mathrm{T}_{2}=$ Industrial effluents $(50 \%)+$ Distill water $(50 \%)$ & $70.0 \pm 1.88 \mathrm{a}$ & $27.50 \pm 0.65 \mathrm{a}$ & $7.75 \pm 0.48 \mathrm{a}$ & $13.7 \pm 0.63 \mathrm{a}$ & $11.00 \pm 0.41 \mathrm{a}$ & $57.09 \pm 0.65 \mathrm{a}$ \\
\hline $\mathrm{T}_{3}=$ Industrial effluents $(75 \%)+$ Distill water $(25 \%)$ & $65.7 \pm 1.70 \mathrm{ab}$ & $23.25 \pm 0.85 \mathrm{bc}$ & $6.00 \pm 0.71 \mathrm{~b}$ & $10.1 \pm 0.80 \mathrm{bc}$ & $9.00 \pm 0.41 \mathrm{bc}$ & $54.54 \pm 0.73 \mathrm{bc}$ \\
\hline $\mathrm{T}_{4}=$ Pure industrial effluents $(100 \%)$ & $62.9 \pm 1.84 \mathrm{bc}$ & $21.25 \pm 0.85 \mathrm{c}$ & $5.25 \pm 0.48 \mathrm{~b}$ & $8.7 \pm 0.98 \mathrm{c}$ & $7.75 \pm 0.48 \mathrm{c}$ & $52.06 \pm 0.53 \mathrm{~d}$ \\
\hline $\mathrm{T}_{5}=$ Acid rain $(\mathrm{HCl}$ at $\mathrm{pH} 3.5)$ & $57.5 \pm 2.42 \mathrm{c}$ & $15.00 \pm 0.71 \mathrm{~d}$ & $3.00 \pm 0.41 \mathrm{c}$ & $5.4 \pm 0.51 \mathrm{~d}$ & $5.50 \pm 0.29 \mathrm{~d}$ & $48.91 \pm 0.72 \mathrm{e}$ \\
\hline $\operatorname{LSD}(p \leq 0.05)$ & 5.71 & 5.71 & 1.52 & 2.2 & 1.52 & 2.02 \\
\hline F-value & $5.14 * *$ & $27.40 * *$ & $9.16 * *$ & $14.50 * *$ & 18.20 ** & $18.50 * *$ \\
\hline
\end{tabular}

PH = Plant Height; PPP = Pods per Plant; NPP = Nodules per plant; PL = Pod length; NGPP = Number of Grains per Pods; SW = Seed weight; Any two means within a column followed by same letters are not significant at $p \leq 0.05 . \mathrm{n}=4 ; * *=$ Highly Significant at $p \leq 0.01$ 


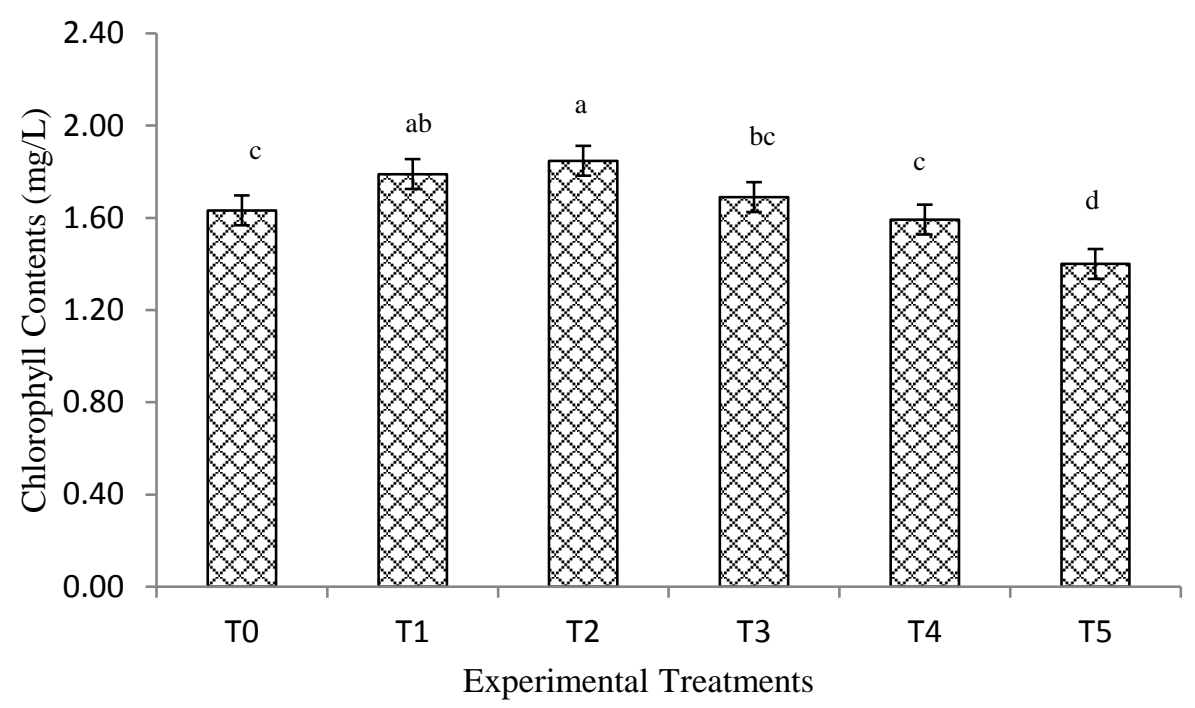

Figure 1. Effect of industrial effluents and simulated acid rain on chlorophyll contents (mg $\mathbf{L}^{-1}$ ) of mungbean



Figure 2. Effect of industrial effluents and simulated acid rain on seed yield $\left(\mathrm{g} \mathrm{pot}^{-1}\right)$ of mungbean 


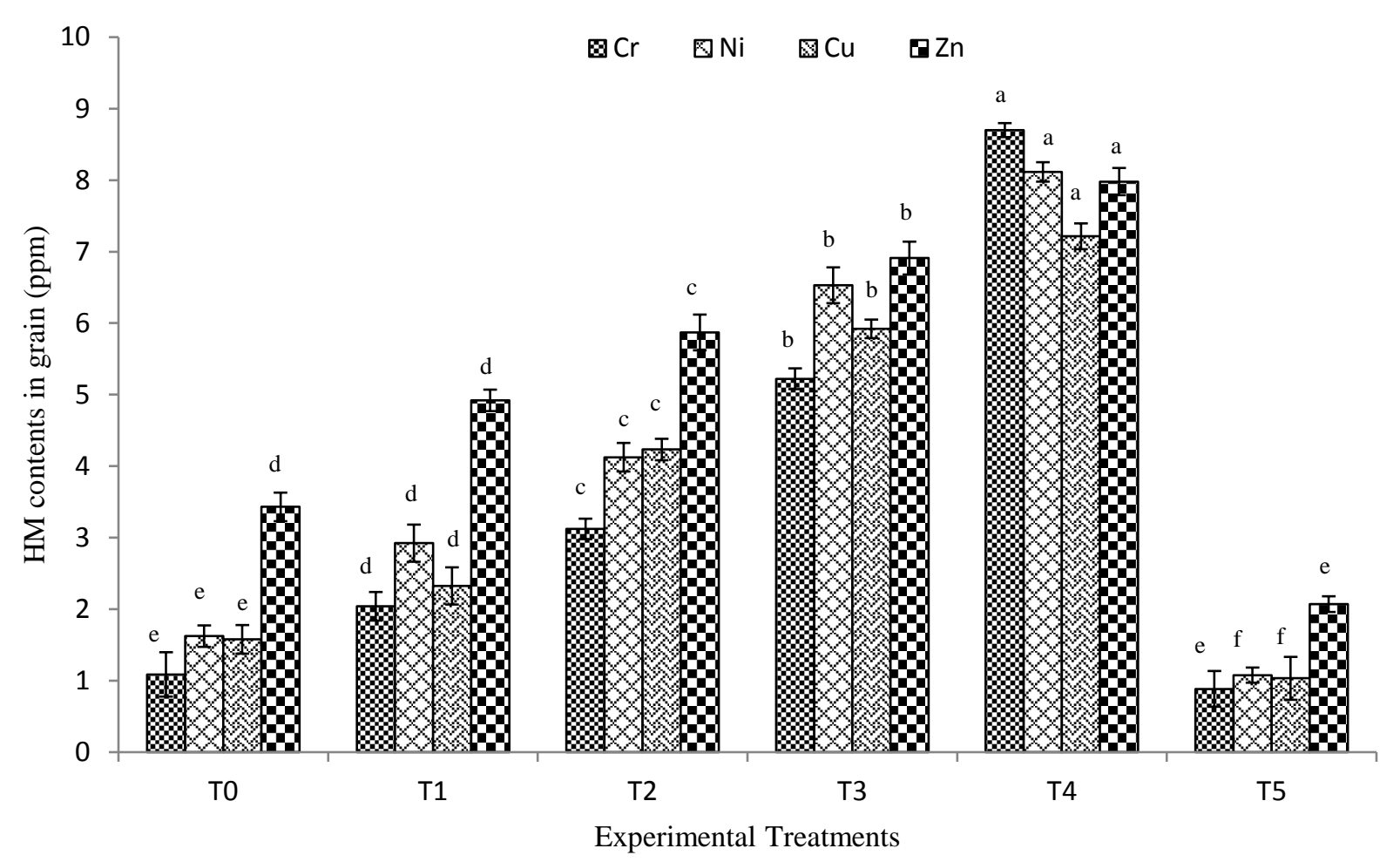

Figure 3. Effect of industrial effluents and simulated acid rain on heavy metal (HM) contents (ppm) in grains of mungbean

Similarly, Begum et al. [23] concluded that distillery wastewater causes a significant reduction on the roots of the rice plant than the shoot growth. These effects were maximum where the $100 \%$ pure effluent was applied because the amount of dissolved materials (cations and anions) that are in pure form might be injurious to germination and growth of the seedling. The availability of metallic micro-nutrients serves as co-factors and activators in enzyme reaction by forming metal enzyme complex [24]. Enhancement in all growth attributes at equal levels (50\%) may be attributed due to the stimulation of auxin which regulated cell elongation. This was supported by the results of micro and macro element induced in the enhancement of seedling growth at lower concentrations obtained by Tomeulescue et al. [25]. But it was inhibited in all effluent at highest concentrations in case of wheat, and even lower growth attributes were observed.
Such type of enhanced effect on the fresh and dry weight of seedling by the application of effluents may be owed to lack of enough mobilization of reserved food to the seedlings. The reserve food materials stored in cotyledons are not mobilized where the growth is inhibited and increase the dry weight of shoot whereas when growth is enhanced, it is mobilized to root and decreased the dry weight of shoot. Increase or decrease of dry biomass in case of diverse groups of Brassica crops was obtained by Pandey et al. [26] with the action of various concentrations of industrial effluents. The breakdown of reserve food materials supplies energy. When seeds germinate and develop into a seedling in the dark, the size, fresh and dry biomass increases greatly [22]. Higher growth leads to the higher expense of reserve food and subsequent decrease in dry weight. It has been reported that industrial effluents raise heavy metal concentration when applied 
to the soil [27]. As root portion of the plant has direct contact with metallic ions in growth media, the upward translocation of metals to shoot due to the endodermic and pericyclic barrier is also slow, which partly prevents upward transport [28]. The results specified that under the stress of SAR, the fresh and dry biomass decreased with the $\mathrm{pH}$ value of acid rain. All the growth, fresh and dry weight, and yield attributes might also have decreased due to thinner mesophyll cells. Reduction in all the growth and yield attributes conforms to the observation of Tong and Liange [29]. All the above facts may be the causes for alteration in fresh and dry weight of root in test crop of this study.

From this study it is obvious that all the industrial effluents at various levels and simulated acid rain treatments pointedly affected the height of plant, number pods in each plant, nodules per plant, pod length, number of grains per plant, 1000-seeds weight, chlorophyll contents and seeds yield of the mungbean plants. Enhancement in all the yield and biochemical attributes which was observed that irrigation with the industrial effluent $(50 \%)$ and distilled water (50\%) might be due to the increased fertility of soil especially concerning organic carbon, phosphorus, and potassium. However, the yield attributes were less in those pots which were irrigated with $(100 \%)$ effluent water. This may be due to low $\mathrm{pH}$ value, high sodium content and heavy metals present in effluent water. These results are supported by the Sajid et al. [30] who reported that seedling growth, chlorophyll contents and yield attributes of crop plants showed a steady decline with the rise in the concentration of effluent. At $25 \%$ effluent concentration the better growth was recorded for the plants.

Similarly, Medhi et al. [31] stated that gradually decline in the yield attributes with the increasing concentration of the effluent was observed. However, the rate of inhibition was observed different for different crop plants. These results are also supported various studies which showed that best germination and seedling growth, root-shoot length, fresh and dry weight, and overall yield was noticed with by the application of $20 \%$ effluent concentration of sago factory that showed the promoting effect in the observed attributes as compared to control. Beyond $20 \%$ effluent concentration, all the studied attributes decreased. Significant decrease in the plant biomass might be due to impairment of chlorophyll which leads to stunted growth of plants. These results are in line with the work of Huang et al. [32] who observed that the decrease in chlorophyll content was observed when pepper and tomato plants were exposed to various concentration of SAR. The main cause behind the reduction in the chlorophyll contents was due to the accumulation of hydrogen ions in the tissues of the plant displacing magnesium ions in the molecule of chlorophyll thereby, retarding the chlorophyll by altering chlorophyll to pheophytin molecule, which cannot carry out the process photosynthesis. These results are in line with the result of Arti et al. [33] and Das et al. [34]. Reduction in the fresh and dry biomass, chlorophyll contents and poor growth leads to the reduced photosynthetic activity that results in lower production of glucose and essential nutrients that result in reduced yield attributes and the overall yield of the mungbean crop plants. A similar observation was also noted by Fan and Wang, [35].

From the current study, it is clear that all the industrial effluents at various levels significantly increase the contents of the metal ( $\mathrm{Zn}, \mathrm{Cu}, \mathrm{Cr}$ and $\mathrm{Ni}$ ) in grains of mungbean plants. Similar observations were observed by Wins and Murugan, [36] who studied that various concentrations of industrial wastes increases the concentration of $\mathrm{Fe}, \mathrm{Cu}, \mathrm{Zn}$, and $\mathrm{Mn}$ in the grains of barley. 
It was noticed that pollutants accumulation occurred in the consumable part of plants and through the food chain, these contaminants reached the consumers and caused numerous harmful effects $[37,38]$. Similarly, Jadoon et al. [39] conducted a study in which irrigation was applied by using wastewater released from various industries and found that metals accumulation such as $\mathrm{As}, \mathrm{Ni}, \mathrm{Zn}, \mathrm{Cr}, \mathrm{Cd}$, and $\mathrm{Pb}$ can be increased where $100 \%$ pure effluents were applied [40].

From all the above observations, this study suggests the necessity of pretreatment of effluent before discharge. It is observed that a higher dilution (industrial effluents $(50 \%)+$ distilled water $(50 \%)$ has a less effect on growth, yield and quality attributes of the mungbean than that of low dilution where pure $100 \%$ effluents were used. So, it is essential to dilute the effluent properly for the utilization in agriculture. The study suggested that the effluent could be used safely for agricultural purpose if used with proper dilution.

\section{Conclusion}

It was concluded that industrial effluents at proper dilution $(50 \%)$ significantly increased the growth, biochemical, yield attributes and metals contents in the grains of the mungbean. However, simulated acid rain $(\mathrm{HCl}$ at $\mathrm{pH} 3.5)$ reduced the growth, productivity, biochemical and quality attributes as compared to control. Application of industrial effluents can be used safely for mungbean cultivation, only after proper treatment and dilution. As a result, to eliminate water limitations without harming the environment, diluted raw wastewater can be used for irrigation by taking precautions such as the necessary drainage and the appropriate irrigation methods.

\section{Authors' contributions}

Conceived and designed the experiments: QU Zaman, Performed the experiments: S Nazir, Analysed the data: S Sharif, contributed materials/ analysis/ tools: S Sharif, Wrote the paper: S Nazir, F Hassan \& U Riaz.

\section{Acknowledgments}

We are thankful to the staff of Soil and Water Testing Laboratory, Lahore for providing us research facilities to execute the research work.

\section{References}

1. Tripathi AK \& Gautam M (2007). Biochemical parameters of plants as indicators of air pollution. J Environ Biol 28: 127-132.

2. Dwivedi AK \& Tripathi BD (2007). Pollution tolerance and distribution pattern of plants in surrounding areas of coal-fired industries. J Environ Biol 28: 257-263.

3. Rai R, Rajput M, Agrawal M \& Agrawal SB (2011). Gaseous air pollutants: A review on current and future trends of emissions and impact on agriculture. $J$ Sci Res 55: 77-102.

4. Joshi PC \& Chauhan A (2008). Performance of locally grown rice plants (Oryza sativa L.) exposed to air pollutants in a rapidly growing industrial area of district Haridwar, Uttarakhand. Indian J Life Sci 5: 41-45.

5. Bouwman AF, Vuuren DPV, Derwent RG \& Posch M (2002). A global analysis of acidification and eutrophication of terrestrial ecosystem. Water Air Soil Poll 141: 349-382.

6. Lee Y, Park J, Im K, Kim K, Lee J, Lee K, Park J, Lee T, Park D, Yang J, Kim D \& Lee S (2006). Arabidopsis leaf necrosis caused by simulated acid rain is related to the salicylic acid signaling pathway. Plant Physiol Biochem 44: 3842.

7. Singh A \& Agrawal M (2008). Acid rain and its ecological consequences. J Environ Biol. 29: 15-24.

8. Bhati M \& Singh G (2003). Growth and Mineral Accumulation in Eucalyptus 
camaldulensis Seeding Irrigated with Mixed Industrial Effluents. Bioresource Technol 88: 221-228.

9. Jolly YN \& Islam A (2007). Transfer of metals from soil to vegetables and possible health risk assessment. Springer Plus, 2: 385-390.

10. Bhuiyan MAH, Chamhuri S, Ismail SM \& Islam R (2011). The Role of Home Stay for Ecotourism Development in East Coast Economic Region. American J Appl Sci 8: 540-546.

11. Naddafi K, Jaafarzadeh N, Mokhtari M, Zakizadeh B \& Sakian MR (2004). Effects of wastewater stabilization pond effluent on agricultural crops. Inter $J$ Environ Sci Technol 1: 273-277.

12. Tomar SS, Sing R \& Sing PS (2004). Response of phosphorous, sulphur and rhizobium inoculation on growth, yield and quality of mungbean. Prog Agri 4: 72-73.

13. Ahmad R, Ikram M, Ehsanullah \& Mahmood A (2003). Influence of different fertilizer levels on the growth and productivity of three mung bean (Vigna radiata $\mathrm{L}$ ) cultivar. Inter J Agri Biol 5: 335-338.

14. Ashraf M, Mueen Ud Din M \& Warrich $N$ (2003). Production efficiency of mungbean (Vigna radiata $\mathrm{L}$ ) as affected by seed inoculation and NPK application. Int J Agri Biol 12: 179-180.

15. Clesceri LS, Greenberg AE \& Eaton AD (1998). Standard methods for the examination of water and wastewater. $20^{\text {th }}$ ed. American Public Health Association, Washington, pp 1325.

16. Rab A, Khan MR, Haq SU, Zahid S, Asim M, Afridi MZ, Arif M \& Munsif F (2016). Impact of biochar on mungbean yield and yield components. Pure Appl Biol 5(3): 632-640.

17. Nagata M \& Yamashita I (1992). Simple method for the simultaneous determination of chlorophyll and carotenoids in tomato fruits. J Japan Soc Food Sci Feclinol 39: 925-928.

18. Jones JRJ \& Case VW (1990). Sampling, handling, and analyzing plant tissue samples. pp. 389-428. In: R.L. Westerman (ed.) Soil Testing and Plant Analysis ( ${ }^{\text {rd }}$ Ed.). Soil Science Society America, Madison, USA.

19. Jolly YN, Islam A \& Mustafa AI (2012). Impact of dyeing industry effluent on soil and crop. Uni J Environ Res Technol 2: 560-568.

20. Kanu I \& Achi OK (2011). Industrial effluents and their impact on water quality of receiving rivers in Nigeria. $J$ Applied Technol Environ Sanitat 1: 7586.

21. Hossain ML, Huda SMS \& Hossain MK (2009). Effects of industrial and residential sludge on seed germination and growth parameters of Acacia auriculiformis seedlings. J Forest Res 20: 331-336.

22. Medhi UJ, Talukdar AK \& Deka S (2011). Impact of paper mill effluent on growth and development of certain agricultural crops. $J$ Environ Biol 32:185-188.

23. Begum RA, Zaman MW, Mondol ATMAI, Islam MS \& Hossain KMF (2011). Effects of textile industrial wastewater and uptake of nutrients on the yield of rice. Bangladesh J Agri Res 36: 319-331.

24. Lauchli A \& Luttge U (2000). Salinity Environments-Plants Molecules, Kluwer Academic Publishers, Dordrecht, The Netherlands.

25. Tomeulescue IM, Radoviciu EM, Merca VV \& Tuduce AD (2004). Effect of copper, zinc and lead and their combinations on the germination capacity of two cereals. J Agri Sci 15: 39-42. 
26. Pandey AK, Dutta $S$ \& Sharma KC (2002). Impact of marble slurry on sub surface water- A case study of Kishangarh district Ajmer. Environ Pollution Technol 1: 5-11.

27. Begum SA, Alam MJ, Rahman SS \& Rahman MM (2010). Effect of industrial effluents on the germination and seedling growth of three leafy vegetables. Bangladesh J Sci Res 45: 101-104.

28. Chhonkar PK, Datta SP, Joshi HC \& Pathak H (2000). Impact of industrial effluents on soil health and agriculture Indian experience: Part-I, distillery and paper mill effluents. J Indian Sci Res 59: 350-361.

29. Tong G \& Liange H (2005). Effect of simulated acid rain and its acidified soil on soluble sugar and nitrogen contents of wheat seedlings. Xin Young Sheng Tai Хие Bao 16: 1487-1492.

30. Sajid A, Tabassum A \& Masood A (2015). The effect of industrial effluents on crop plants: a review. Inter J Res Eng Soc Sci 5(6): 14-26.

31. Medhi UJ, Talukdar AK \& Deka S (2008). Effect of pulp and paper mill effluent on seed germination and seedling growth of Mustard (Brassica campestris), Pea (Pisum sativam) and Rice (Oryza sativa) seeds. Pollution Res 27: 437-442.

32. Huang XH, Zeng OL \& Zhou Q (2005). Effect of acid rain on seed germination of rice, wheat and grape. Huan Jing Kexue 26: 181-184.

33. Arti V, Ashish T \& Abdullah A (2010). An impact of simulated acid rain of different $\mathrm{pH}$ levels on some major vegetable plants in India. Res Opin 2: 3840.
34. Das N, Das R \& Chaudhury GR (2010). Chemical composition of precipitation at background level. Atmospheric Res 95: 108-113.

35. Fan HB \& Wang YH (2000). Effects of simulated acid rain on germination, foliar damage, chlorophyll contents and seedling growth of five hardwood species growing in Simulated acid rain on rice plant China. Forest Ecol Manag 126: 321-329.

36. Wins JA \& Murugan M (2010). Effect of textile mill effluent on growth and germination of black gram (Vigna mungo L.) Hepper. Inter J Pharmacy and Biol Sci 1: 1-7.

37. Barar MS, Mahli SS, Singh AP \& Aroroa CL (2000). Sewer water irrigation effects on some potentially toxic trace elements in soil and potato plants in northwestern. Canadian J Soil Sci 80: 465-471.

38. Panaskar DB \& Pawar RS (2011). Effect of textile mill effluent on growth of Sorghum vulgare and Vigna aconitifolia seedlings. Indian J Sci Technol 4: 273278.

39. Jadoon IBK, Ali S, Jadoon QBK, Shakoor MB, Bharwana SA \& Farooq MA (2013). Effects of irrigation with waste water from different industries on vegetables grown in vicinity of Faisalabad, Pakistan. Inter J Plant Sci 4: 144-148.

40. Rattan RK, Datta SP, Chhonkar PK, Suribabu K \& Singh AK (2005). Longterm impact of irrigation with sewage effluents on heavy metal content in soils, crops and groundwater- a case study. Agro Ecosystem Environ 109: 310-322. 